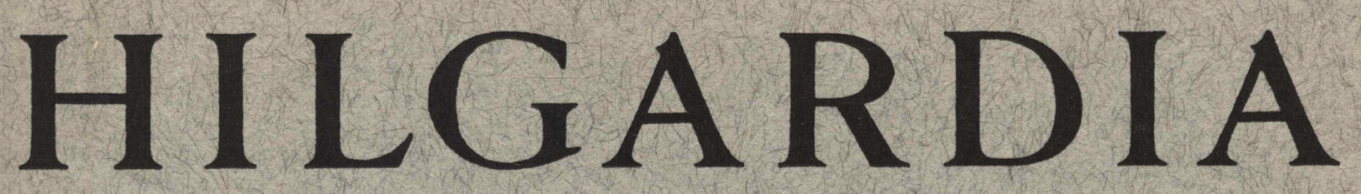

A Journal of Agricultural Science Publisbed by the California Agricultural Experiment Station

\title{
THE EFFECTS OF DATES OF HARVEST OPERATIONS ON YIELD AND QUALITY OF PINK BEANS
}

\author{
FRANCIS L. SMITH
}


Experiments in Sutter County and at Davis, California, to determine the effect of dates of cutting and threshing on yield, bean size, and percentage of browning in varieties of Pink beans indicate that:

- Cutting a week before beans reach maturity greatly reduces browning but also reduces yield and bean size.

- Percentage of brown beans increases rapidly with exposure, either standing in the field or in the windrow.

- The percentage of browning is lower in Sutter Pink than in other varieties tested, and lower in Sutter County than at Davis. Varietal differences may be associated with weather conditions at the time of harvest. The experimental harvest period extended over a period of 10 weeks, but for any one variety it was only 5 weeks.

In order to keep browning to a minimum without reducing yield and bean size, a grower should cut his beans as soon as they are ripe and thresh them as soon as they are dry. Delays in either cutting or threshing increase the browning. 


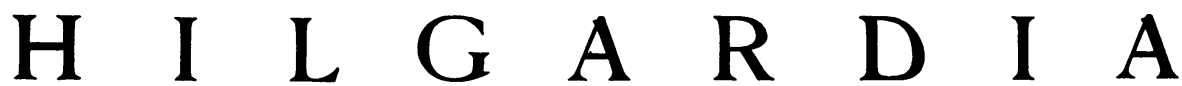

A Journal of Agricultural Science Published by

the California Agricultural Experiment Station

VoL. 24

AUGUST, 1955

No. 2

\section{THE EFFECTS OF DATES OF HARVEST OPERATIONS ON YIELD AND QUALITY OF PINK BEANS ${ }^{1}$}

FRANCIS L. SMITH

There have been some complaints that Sutter Pink beans become brown to some extent during harvest before they are cleaned and ready for the market. At the request of growers in Sutter County, a study of the problem was initiated in that county in 1952. The experiment was conducted with Sutter Pink, cut before ripe, when ripe, and when overripe. Half of the plots at each cutting date were threshed a week after cutting and the other half about a week later. The results of this study, reported in California Agriculture, ${ }^{3}$ indicated the following.

1. Yield was sacrificed if the beans were cut a week before they were actually ripe.

2. Size of the beans was reduced by early cutting.

3 . The percentage of brown beans increased from 22 to 39 in 21 days of exposure.

This test left some gaps in the information, which were to be supplied in the 1953 experiments. These were:

1. In 1952 the intervals between cutting and threshing dates were not always equal. Since the time factor is important, the experiments in 1953 were set up on a regular time schedule.

2. The minimum amount of browning obtained in 1952 was 22 per cent. These beans, however, had been exposed a week in the drying process. In the 1953 experiments one treatment was made to give a zero exposure. A sample was taken at each date of cutting and dried artificially without further exposure.

3. If browning is due to exposure, the length of exposure should be extended in some treatments. In the 1953 tests, therefore, three weekly dates of threshing were made rather than two.

4. Only one Pink variety was tested in 1952. The tests in 1953 were expanded to include four Pink varieties. It seemed necessary to determine whether all Pink varieties showed the same amount of browning or if there were enough varietal differences to warrant changing varieties.

\footnotetext{
${ }^{1}$ Received for publication December 6, 1954.

2 Associate Professor of Agronomy and Associate Agronomist in the Experiment Station, Davis, California.

${ }^{3}$ Smith, Francis L., and John H. Lindt. Harvesting Sutter Pink beans. California Agr. $7(10): 15$. October, 1953.
} 

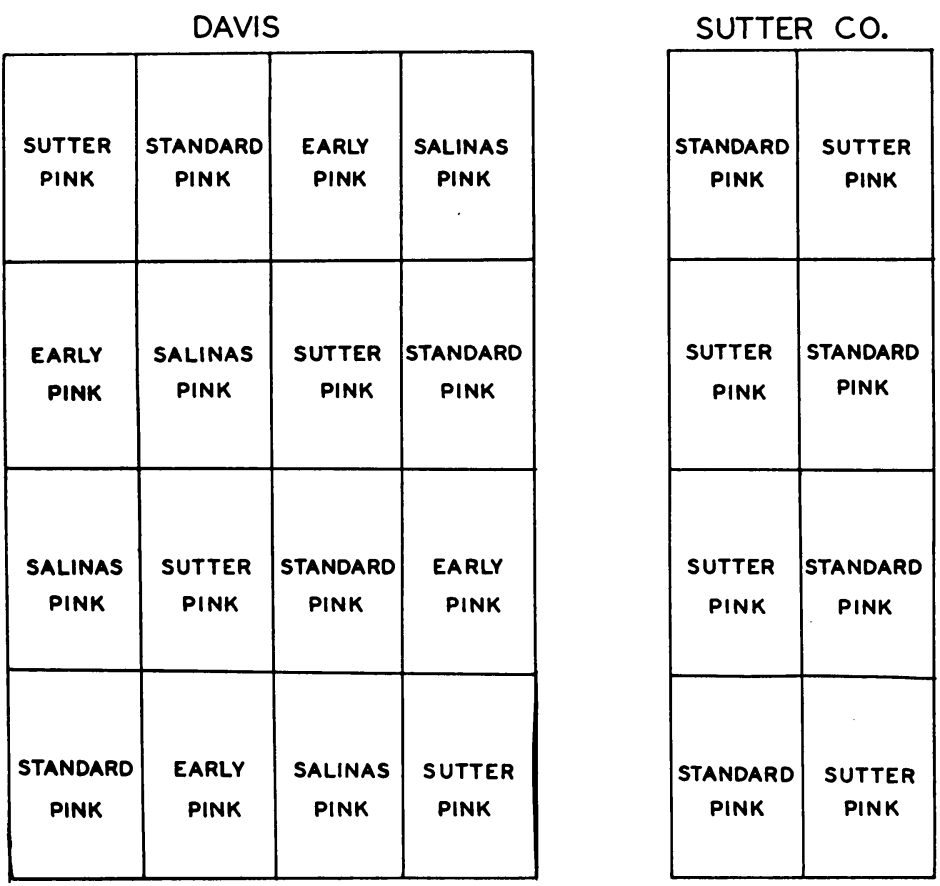

NINE TREATMENTS IN EACH BLOCK

\begin{tabular}{|c|c|c|}
\hline $\begin{array}{c}\text { CUT 1 } \\
\text { THRESH 0 } \\
\text { THRESH 1 }\end{array}$ & $\begin{array}{c}\text { CUT 1 } \\
\text { THRESH 2 }\end{array}$ & $\begin{array}{c}\text { CUT 1 } \\
\text { THRESH 3 }\end{array}$ \\
\hline $\begin{array}{c}\text { CUT 2 } \\
\text { THRESH 0 } \\
\text { THRESH 1 }\end{array}$ & $\begin{array}{c}\text { CUT 2 } \\
\text { THRESH 2 }\end{array}$ & $\begin{array}{c}\text { CUT 2 } \\
\text { THRESH 3 }\end{array}$ \\
\hline $\begin{array}{c}\text { CUT 3 } \\
\text { THRESH 0 } \\
\text { THRESH 1 }\end{array}$ & $\begin{array}{c}\text { CUT 3 } \\
\text { THRESH 2 }\end{array}$ & $\begin{array}{c}\text { CUT 3 } \\
\text { THRESH 3 }\end{array}$ \\
\hline
\end{tabular}

Fig. 1. Plan of experiments on harvest treatments of Pink beans at Davis and in Sutter County, 1953. Upper diagram, arrangement of variety plots; lower diagram, treatments used in each plot. The distribution of treatments varied in a random manner.

5. The tests in 1952 were confined to one locality. In 1953 they were made in two. The Experiment Station at Davis was chosen for one test because the work required close attention, best given at the home station. The tests in Sutter County were expanded to two varieties. In planning and executing the harvest of the Sutter County plots, Mr. Lindt gave valuable assistance. 


\section{PLAN OF THE 1953 EXPERIMENTS}

The major interest in the tests was the harvest treatments. In the design of the experiments, therefore, the treatments were more critical than the varieties. At each location the main plots consisted of varieties - two in Sutter County and four at Davis. Each variety plot was replicated four times at both locations-in a randomized fashion in Sutter County and in a $4 \times 4$ Latin square at Davis, as shown in figure 1.

The subplots in both locations consisted of nine treatments which were randomized in each main plot. Each subplot was 4 rows wide and 30 feet

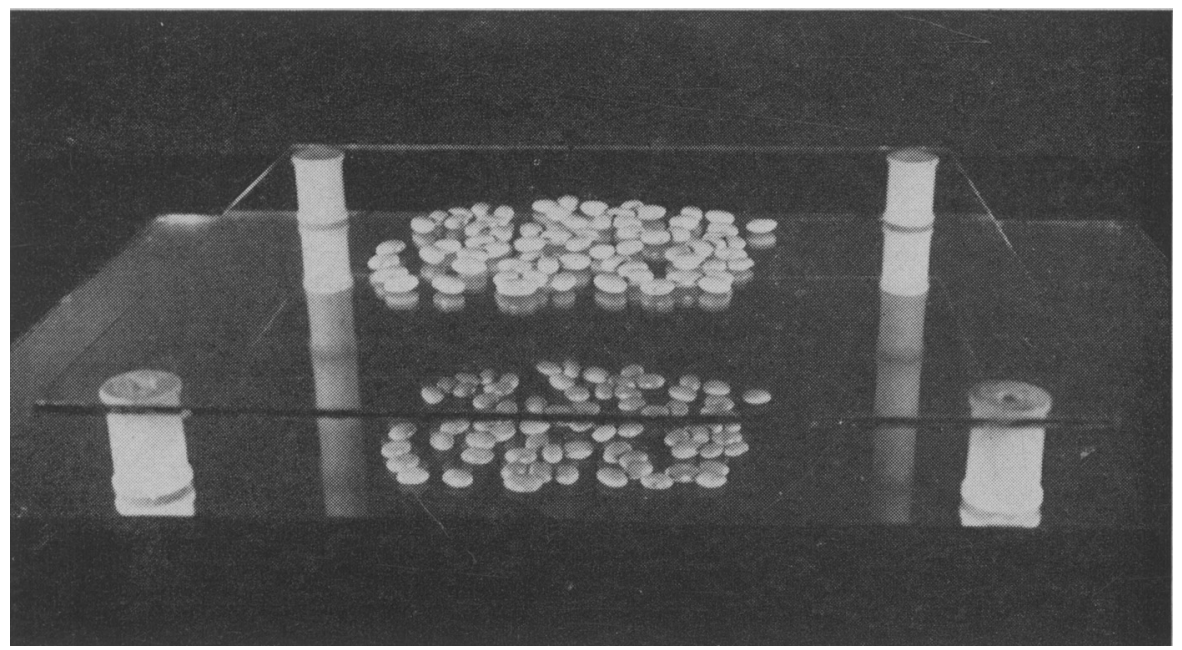

Fig. 2. Apparatus for determining the brown beans in 100-bean samples. The mirror below enables the observer to see both sides of each bean.

long. Only the two center rows of the subplots were harvested. The nine harvest treatments were all the combinations of three cutting and three threshing dates. The three cutting dates were: cut 1 , a week before ripe; cut 2 , when ripe; and cut 3 , a week overripe. Since these tests were set on weekly schedules it was planned to do the harvesting work on the same day each week. The date of the first cutting of a variety then had to be estimated to be as nearly as possible a week before the beans were ripe. In these beans if there is color around the hilum, the beans can be cut with no danger of shrinkage upon drying. On the first cutting date many of the beans were not that mature. Three plots were cut in each of the main plots on any given cutting date. One of these was threshed a week after cutting (thresh 1). Another was threshed after two weeks (thresh 2) and the last was threshed three weeks after cutting (thresh 3 ).

In order to obtain the minimum exposure time another treatment, called thresh 0 , was made by taking a sample of beans from the guard rows at each cutting date and drying it artificially. These samples were kept out of the light both before and after they were threshed. With thresh 0 included there were twelve treatments. 
ANALYSES OF VARIANCE OF YIELDS OF PINK BEANS AS INFLUENCED BY HARVEST TREATMENTS, 1953

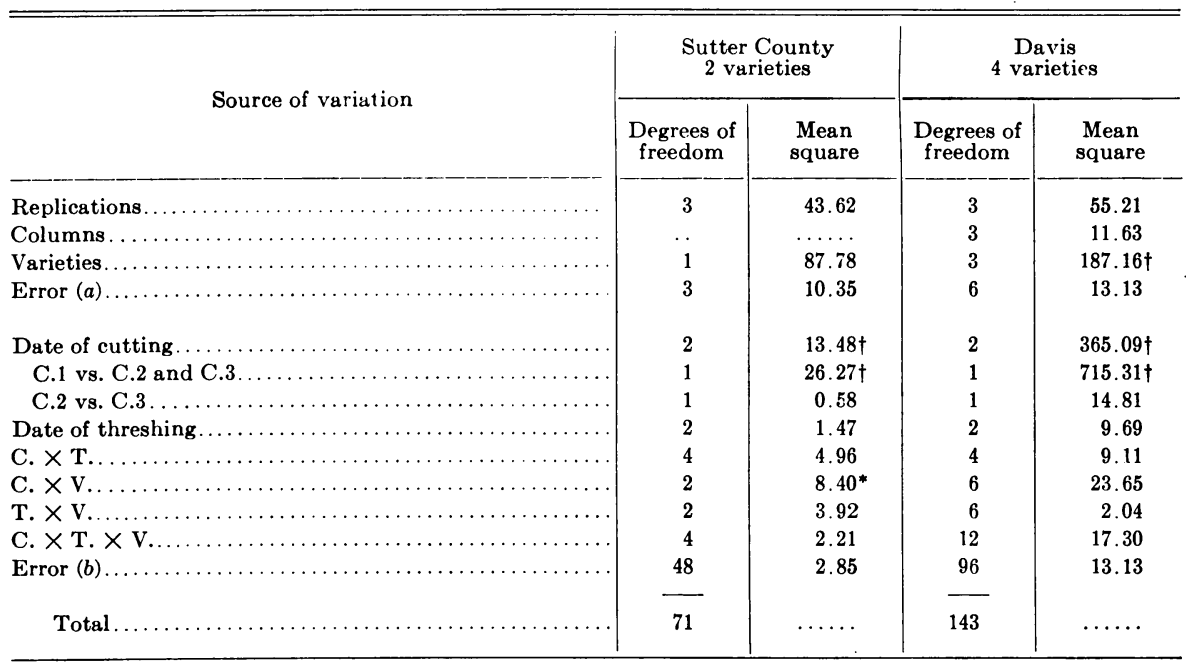

* $F$ values indicate significance at the 5 per cent level (odds 19:1).

$\dagger F$ values indicate significance at the 1 per cent level (odds 99:1).

TABLE 2

YIELD OF PINK BEAN VARIETIES AT DIFFERENT CUTTING DATES, SUTTER COUNTY, 1953

\begin{tabular}{|c|c|c|c|c|c|c|}
\hline \multirow{2}{*}{ Variety } & \multirow{2}{*}{$\begin{array}{c}\text { Date of } \\
\text { first } \\
\text { cutting }\end{array}$} & \multicolumn{5}{|c|}{ Yield in hundredweights per acre } \\
\hline & & Cut 1 & Cut 2 & Cut 3 & L.S.D. & Average \\
\hline Sutter Pink.............. & Sept. 11 & 21.18 & 22.57 & 23.69 & 1.39 & 22.48 \\
\hline Standard Pink..... & Sept. 25 & 19.87 & 20.82 & 20.14 & 1.39 & 20.28 \\
\hline L.S.D......... & $\ldots \ldots \ldots$ & 0.98 & 0.98 & 0.98 & $\cdots$ & 2.41 \\
\hline A verage of both varieties........ & $\ldots \ldots \ldots$ & 20.53 & 21.70 & 21.92 & $\cdots$ & 21.38 \\
\hline
\end{tabular}

TABLE 3

YIELD OF PINK BEAN VARIETIES AT DIFFERENT CUTTING DATES, DAVIS, 1953

\begin{tabular}{|c|c|c|c|c|c|c|}
\hline \multirow{2}{*}{ Variety } & \multirow{2}{*}{$\begin{array}{l}\text { Date of } \\
\text { first } \\
\text { cutting }\end{array}$} & \multicolumn{5}{|c|}{ Yield in hundredweights per acre } \\
\hline & & Cut 1 & Cut 2 & Cut 3 & L.S.D. & Average \\
\hline Early Pink.. & Sept. 1 & 16.66 & 24.54 & 23.82 & 2.93 & 21.66 \\
\hline Sutter Pink.... & Sept. 8 & 21.19 & 24.62 & 26.27 & 2.93 & 24.03 \\
\hline Standard Pink. & Sept. 29 & 24.97 & 26.70 & 28.36 & 2.93 & 26.68 \\
\hline Salinas Pink... & Oct. 6 & 19.06 & 22.73 & 24.55 & 2.93 & 22.11 \\
\hline L.S.D. $\ldots \ldots \ldots \ldots \ldots \ldots \ldots \ldots \ldots \ldots \ldots \ldots \ldots$ & $\ldots \ldots \ldots$ & 2.93 & 2.93 & 2.93 & $\ldots$ & 1.93 \\
\hline Average all varieties.................. & $\ldots \ldots \ldots$ & 20.47 & 24.64 & 25.75 & 1.47 & 23.62 \\
\hline
\end{tabular}


The outlines of the experiments both at Davis and in Sutter County are shown in figure 1. The lower diagram shows the treatments used, but not their distribution, which of course varied in a random manner for the different plots. The planting dates were June 17 for Davis and July 1 for Sutter County.

Three measurements were made on each subplot: yield (calculated in pounds per acre for each subplot), seed size (the weight in grams of 100 beans), and percentage of brown beans. The seed size and percentage of brown beans were determined from four 100-bean samples drawn from each subplot (and for thresh 0, from the guard rows). The browning percentages were determined by picking out the beans which were even slightly brown. In order to see both sides of the beans at once, the observation platform was a sheet of glass placed about an inch above a mirror which was face up on the laboratory table. A picture of the apparatus is shown in figure 2.

The data for each measurement at each location were subjected to an analysis of variance. All the least significant differences in this report are at the 5 per cent level (odds 19:1).

\section{EFFECTS ON YIELD}

Sutter County. The analysis of variance of the data from Sutter County is given in table 1 . This table indicates that the difference in yield between the two varieties was not significant at the 5 per cent level: the Sutter Pink plots averaged $22.48 \mathrm{cwt}$. per acre and the Standard, 20.28, a difference of $2.20 \mathrm{cwt}$., but 2.41 is required for significance. Significant yield differences were found in cutting dates and in the interactions of cutting dates and varieties.

The yields of Sutter and Standard Pink at the three cutting dates are shown in table 2. The results indicate that most of the differences between cutting dates were in the Sutter Pink plots. The experimental plots were established in a commercial field of Sutter Pink beans that was subirrigated. When the commercial beans were ripe the water was withdrawn to harvest the crop. At this time the Standard Pink plots of the experiment were immature, and the yield did not increase at the later cuttings because of lack of moisture. In this variety there were no significant differences between the yields at the three dates of cutting. For this reason the average differences in yield for different cutting dates were not as extreme in the Sutter County experiment as they were at Davis, where moisture was not limited. This is shown in figure 3.

Davis. The analysis of variance for yield of four varieties of Pink beans at Davis is shown in table 1 . There were significant differences only between varieties and between the three cutting dates. Furthermore, the differences between cut 1 and cuts 2 and 3 were highly significant, but those between the second and third cutting dates were not significant. In other words, early cutting reduced yields in all varieties. The threshing treatments did not affect yields. Since variety differences were significant, the yields of each variety at each cutting date are shown in table 3.

In all varieties there was an increase in yield of the second cutting over the first. In all varieties except Early Pink there was a slight increase in the third over the second cutting date; the latter differences were not statistically 
significant, however. Average yields at different cutting dates are shown graphically in figure 3 .

\section{EFFECTS ON SEED SIZE}

Sutter County. An analysis of variance of the size of the beans in Sutter County is given in table 4. There was no significant difference between varieties at the 5 per cent level. The average size of Sutter Pink was 31.5 and Standard Pink, 30.9 grams per 100 beans ; the least significant difference was

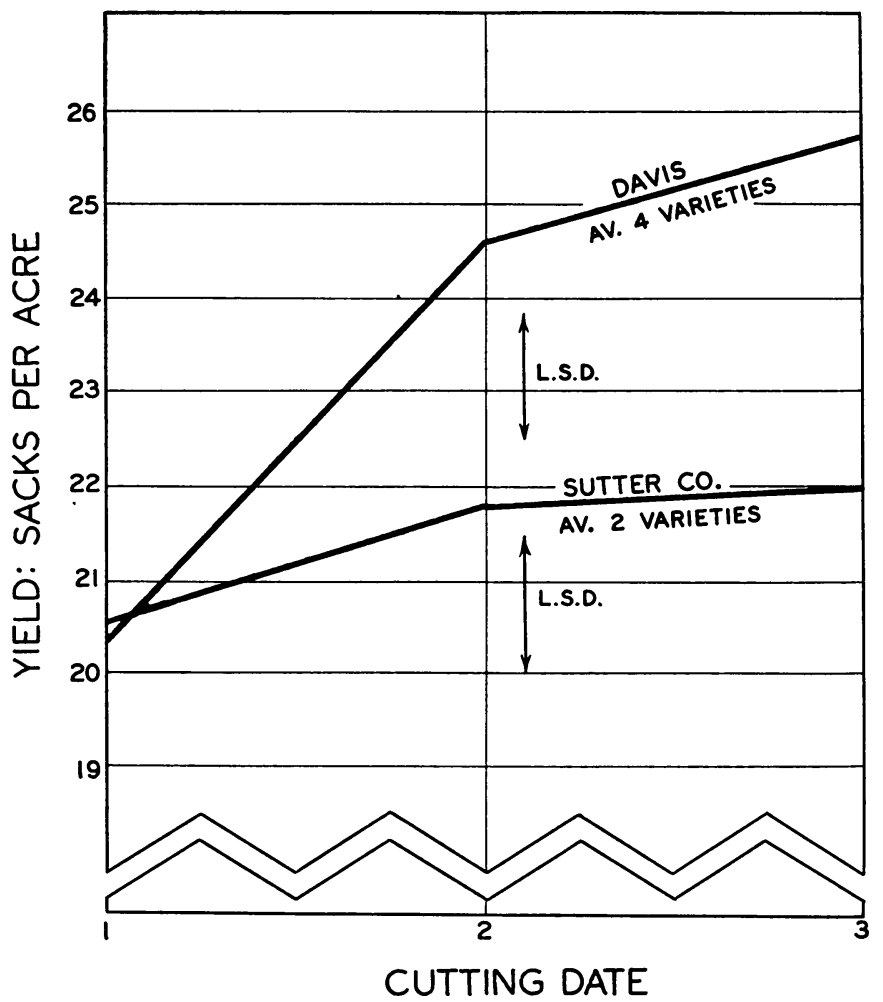

Fig. 3. Effect of date of cutting on yields of Pink beans, 1953.

1.9 grams. There were significant differences between cutting dates and between threshing dates, but none of the interactions were significant. Since the differences between varieties were not significant, only the treatment differences are shown in table 5. From the data given in table 5 it is apparent that all earliest-cut plots had smaller seed than the two succeeding cutting dates. These results are shown graphically in figure 4 .

The cut 1 thresh 0 treatment had the smallest seed, indicating the beans had become drier and hence lighter under artificial drying conditions than those cut at the same time and cured in the field, or else the bean plants which were cut and dried immediately had less time to translocate material from the plant. Further evidence that moisture content has an influence on the weight of the beans is given by comparing all plots cut early: the seed size 
TABLE 4

ANALYSES OF VARIANCE OF SEED SIZE OF PINK BEANS AS INFLUENCED BY HARVEST TREATMENTS, 1953

\begin{tabular}{|c|c|c|c|c|}
\hline \multirow[b]{2}{*}{ Source of variation } & \multicolumn{2}{|c|}{ Sutter County } & \multicolumn{2}{|c|}{ Davis } \\
\hline & $\begin{array}{l}\text { Degrees of } \\
\text { freedom }\end{array}$ & $\begin{array}{l}\text { Mean } \\
\text { square }\end{array}$ & $\begin{array}{l}\text { Degrees of } \\
\text { freedom }\end{array}$ & $\begin{array}{l}\text { Mean } \\
\text { square }\end{array}$ \\
\hline Replications $\ldots \ldots \ldots \ldots \ldots \ldots \ldots \ldots \ldots \ldots \ldots \ldots$ & 3 & 24.21 & 3 & 4.59 \\
\hline 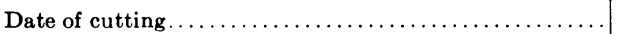 & 2 & $74.40 \dagger$ & 2 & $588.68 \dagger$ \\
\hline 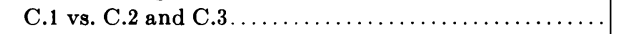 & 1 & $148.41 \dagger$ & 1 & $1,148.86 \dagger$ \\
\hline C. 2 vs. C. $3 \ldots \ldots \ldots \ldots \ldots \ldots \ldots \ldots \ldots \ldots \ldots \ldots \ldots$ & 1 & 0.38 & 1 & $28.50 \dagger$ \\
\hline Date of threshing........... & 3 & $11.15 \dagger$ & 3 & $81.05 \dagger$ \\
\hline 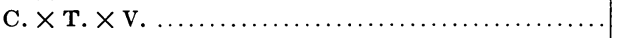 & 6 & 4.16 & 18 & $5.73 \dagger$ \\
\hline 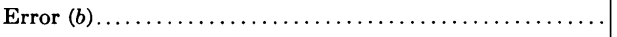 & 48 & 2.05 & 132 & 2.19 \\
\hline 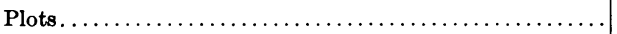 & 95 & $6.12 \dagger$ & 191 & $35.95 \dagger$ \\
\hline 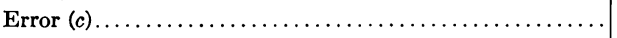 & 288 & 0.38 & 576 & 1.03 \\
\hline Total............... & 383 & $\ldots \ldots$ & 767 & $\ldots \ldots \ldots$ \\
\hline
\end{tabular}

$\dagger F$ values indicate significance at the 1 per cent level (odds 99:1).

TABLE 5

EFFECT OF CUTTING AND THRESHING DATES ON SEED SIZE OF TWO VARIETIES, SUTTER COUNTY, 1953

\begin{tabular}{|c|c|c|c|c|c|c|}
\hline \multirow{2}{*}{ Cutting dates } & \multicolumn{6}{|c|}{ Seed size, grams per 100 beans } \\
\hline & Thresh 0 & Thresh 1 & Thresh 2 & Thresh 3 & L.S.D. & Average \\
\hline Cut $1 \ldots$ & 29.6 & 30.7 & 30.5 & 30.3 & 0.7 & 30.3 \\
\hline Cut $2 \ldots$ & 31.2 & 31.5 & 31.8 & 31.7 & 0.7 & 31.6 \\
\hline Cut $3 .$. & 31.2 & 31.2 & 32.0 & 32.1 & 0.7 & 31.4 \\
\hline L.S.D..... & 0.7 & 0.7 & 0.7 & 0.7 & $\ldots$ & 0.4 \\
\hline Average $\ldots \ldots \ldots \ldots \ldots$ & 30.3 & 31.6 & 31.6 & 31.6 & 0.4 & $\ldots$ \\
\hline
\end{tabular}

was smallest in those artificially dried (29.6 grams/100 beans) and largest in those exposed one week ( 30.7 grams) ; beans exposed in the field two weeks weighed 30.5 and three weeks 30.3 grams per 100 beans. The differences between thresh 0 and 1, 0 and 2, are significant, that between 0 and 3 is barely significant at the 5 per cent level.

The greatest differences were between the first and second cutting dates. The seed weight was exactly the same in the cut 2 and cut 3 treatments. The cut 1 thresh 0 samples also had larger amounts of small beans which were screened out in cleaning. This and the lower seed weight indicate that the early cutting did reduce seed size.

Davis. The analysis of variance on seed size in the Davis plots is shown in table 4 . There were highly significant differences between varieties, dates of 
cutting, dates of threshing, and the interactions of cutting and threshing, cutting and varieties, and cutting, threshing, and varieties. The only interaction which was not significant was between dates of threshing and varieties. Since the figures on threshing dates are confounded with cutting dates and since there was interaction between cutting dates and varieties, it seems worth while to present the detailed results for each of the twelve treatments

TABLe 6

EFFECT OF CUTTING AND THRESHING DATES ON SEED SIZE OF FOUR PINK VARIETIES, DAVIS, 1953

\begin{tabular}{|c|c|c|c|c|c|c|c|}
\hline \multirow{2}{*}{ Variety } & \multirow{2}{*}{ Cutting dates } & \multicolumn{6}{|c|}{ Seed size, grams per 100 beans } \\
\hline & & Thresh 0 & Thresh 1 & Thresh 2 & Thresh 3 & L.S.D. & Average \\
\hline Early Pink & 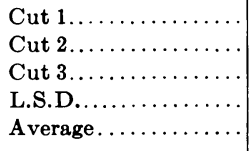 & $\begin{array}{r}26.9 \\
29.8 \\
31.1 \\
1.0 \\
29.3\end{array}$ & $\begin{array}{r}28.5 \\
31.5 \\
32.2 \\
1.0 \\
30.7\end{array}$ & $\begin{array}{r}26.8 \\
31.3 \\
31.8 \\
1.0 \\
30.0\end{array}$ & $\begin{array}{r}26.7 \\
32.2 \\
31.6 \\
1.0 \\
30.0\end{array}$ & $\begin{array}{l}1.0 \\
1.0 \\
1.0 \\
\ldots \\
0.6\end{array}$ & $\begin{array}{r}27.2 \\
31.1 \\
31.7 \\
0.5 \\
30.0\end{array}$ \\
\hline $\begin{array}{r}\text { Sutter } \\
\text { Pink }\end{array}$ & 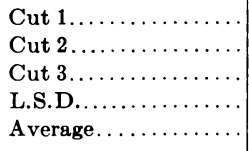 & $\begin{array}{r}29.6 \\
33.5 \\
34.2 \\
1.0 \\
32.4\end{array}$ & $\begin{array}{r}31.9 \\
34.1 \\
35.0 \\
1.0 \\
33.6\end{array}$ & $\begin{array}{r}32.3 \\
34.5 \\
35.0 \\
1.0 \\
33.9\end{array}$ & $\begin{array}{r}31.0 \\
34.0 \\
34.3 \\
1.0 \\
33.1\end{array}$ & $\begin{array}{l}1.0 \\
1.0 \\
1.0 \\
1 . \\
0.6\end{array}$ & $\begin{array}{r}31.2 \\
34.0 \\
34.6 \\
0.5 \\
33.3\end{array}$ \\
\hline $\begin{array}{l}\text { Standard } \\
\text { Pink }\end{array}$ & 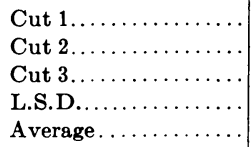 & $\begin{array}{r}33.6 \\
33.6 \\
33.8 \\
1.0 \\
33.6\end{array}$ & $\begin{array}{r}34.6 \\
35.2 \\
35.0 \\
1.0 \\
35.0\end{array}$ & $\begin{array}{r}33.6 \\
35.0 \\
35.9 \\
1.0 \\
34.8\end{array}$ & $\begin{array}{r}33.5 \\
35.4 \\
35.2 \\
1.0 \\
34.7\end{array}$ & $\begin{array}{l}1.0 \\
1.0 \\
1.0 \\
1 . \\
0.6\end{array}$ & $\begin{array}{r}33.8 \\
34.8 \\
35.0 \\
0.5 \\
34.5\end{array}$ \\
\hline $\begin{array}{c}\text { Salinas } \\
\text { Pink }\end{array}$ & 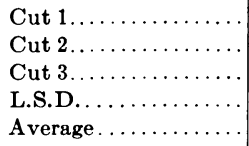 & $\begin{array}{r}25.5 \\
27.6 \\
29.1 \\
1.0 \\
27.4\end{array}$ & $\begin{array}{r}29.2 \\
29.7 \\
29.6 \\
1.0 \\
29.5\end{array}$ & $\begin{array}{r}27.1 \\
29.1 \\
29.5 \\
1.0 \\
28.6\end{array}$ & $\begin{array}{r}26.6 \\
29.0 \\
29.4 \\
1.0 \\
28.3\end{array}$ & $\begin{array}{l}1.0 \\
1.0 \\
1.0 \\
\ldots \\
0.6\end{array}$ & $\begin{array}{r}27.1 \\
28.8 \\
29.4 \\
0.5 \\
28.4\end{array}$ \\
\hline $\begin{array}{l}\text { Average, } \\
\text { four } \\
\text { varieties }\end{array}$ & $\begin{array}{l}\text { Cut } 1 \ldots \ldots \ldots \ldots \ldots \\
\text { Cut } 2 \ldots \ldots \ldots \ldots \ldots \\
\text { Cut } 3 \ldots \ldots \ldots \ldots \ldots \ldots \\
\text { L.S.D. } \ldots \ldots \ldots \ldots \ldots \ldots \\
\text { Average } \ldots \ldots \ldots \ldots \ldots\end{array}$ & $\begin{array}{r}28.9 \\
31.1 \\
32.0 \\
0.5 \\
30.7\end{array}$ & $\begin{array}{r}31.0 \\
32.6 \\
32.9 \\
0.5 \\
32.7\end{array}$ & $\begin{array}{r}29.9 \\
32.5 \\
33.0 \\
0.5 \\
31.8\end{array}$ & $\begin{array}{r}29.4 \\
32.5 \\
32.6 \\
0.5 \\
31.5\end{array}$ & $\begin{array}{l}0.5 \\
0.5 \\
0.5 \\
\cdots \\
0.3\end{array}$ & $\begin{array}{r}29.8 \\
32.2 \\
32.7 \\
0.3 \\
31.6\end{array}$ \\
\hline
\end{tabular}

for each variety. These are shown in table 6 . The variety averages in this study are based on 192 measurements each. Therefore, small differences assure statistical significance if they are consistent. The least significant difference between varieties was 0.8 gram per 100 seeds at the 5 per cent level and 1.1 grams at the 1 per cent level. All variety differences in seed size are highly significant. In ascending order the sizes are: Salinas Pink, 28.4 ; Early Pink, 30.0 ; Sutter Pink, 33.3; and Standard Pink, 34.5 grams per 100 beans. Thresh 0 samples were significantly smaller than thresh 1 in all varieties. The thresh 1 treatments were the largest in every variety except Sutter Pink. In Early Pink and Salinas Pink there was a significant difference between thresh 1 and thresh 2 . The difference between thresh 2 and 3 was not significant in any variety; however, in the average of all varieties a barely significant difference was obtained. 


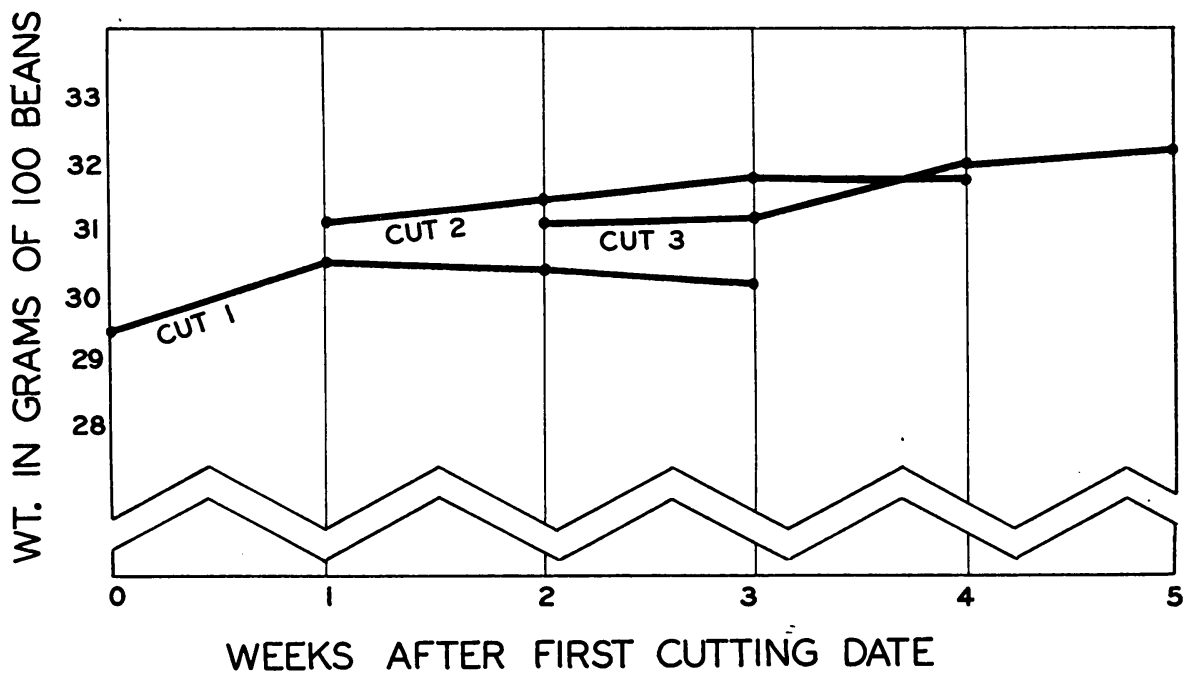

Fig. 4. Effect of date of harvest on size of beans; average of two varieties, Sutter County, 1953.

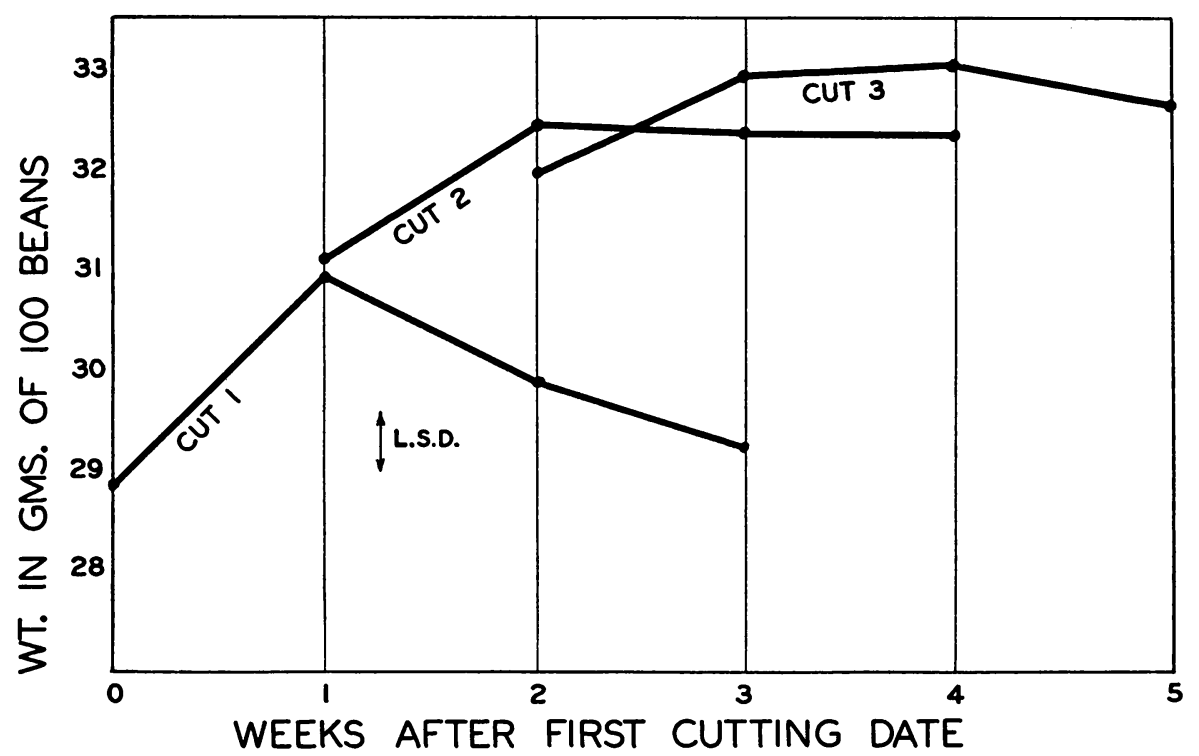

Fig. 5. Effect of date of harvest on size of beans; average of four varieties, Davis, 1953.

An examination of table 6 also shows that there is a significant increase in seed size at each succeeding cutting date for all varieties except Standard Pink, where the difference between the second and third cutting dates is not significant. For every variety the difference is more extreme between the first and second than between the second and third. The beans at the first cutting date were smaller because some were immature when cut; the artificial drying 
ANALYSES OF VARIANCE OF PERCENTAGE OF BROWN BEANS AS INFLUENCED BY HARVEST TREATMENTS, 1953

\begin{tabular}{|c|c|c|c|c|}
\hline \multirow{2}{*}{ Source of variation } & \multicolumn{2}{|c|}{ Sutter County } & \multicolumn{2}{|c|}{ Davis } \\
\hline & $\begin{array}{l}\text { Degrees of } \\
\text { freedom }\end{array}$ & $\begin{array}{c}\text { Mean } \\
\text { square }\end{array}$ & $\begin{array}{l}\text { Degrees of } \\
\text { freedom }\end{array}$ & $\begin{array}{c}\text { Mean } \\
\text { square }\end{array}$ \\
\hline Replications. . & 3 & 39.74 & 3 & 35.38 \\
\hline Varieties...... & 1 & $7,428.96 \dagger$ & 3 & $9,580.41 \dagger$ \\
\hline Error $(a) \ldots \ldots \ldots \ldots \ldots$ & 3 & 62.53 & 9 & 86.06 \\
\hline Date of cutting........ & 2 & $29,597.50 \dagger$ & 2 & $48,151.50 \dagger$ \\
\hline C. 1 vs. C. 2 and C.3. & 1 & $32,669.37 \dagger$ & 1 & $63,101.58 \dagger$ \\
\hline 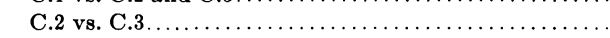 & 1 & $27,245.63 \dagger$ & 1 & $33,201.42 \dagger$ \\
\hline 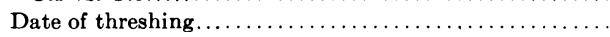 & 3 & $12,399.47 \dagger$ & 3 & $55,493.52 \dagger$ \\
\hline 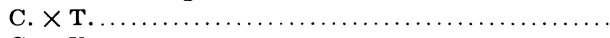 & 6 & $515.58 \dagger$ & 6 & $4,192.43 \dagger$ \\
\hline 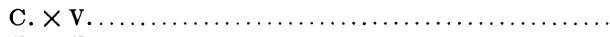 & 2 & $4,168.89 \dagger$ & 6 & $1,417.66 \dagger$ \\
\hline 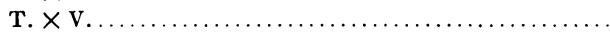 & 3 & $351.86 \dagger$ & 9 & $1,752.76 \dagger$ \\
\hline 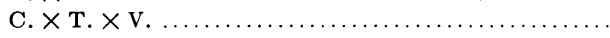 & 6 & $460.22 \dagger$ & 18 & $743.68 \dagger$ \\
\hline 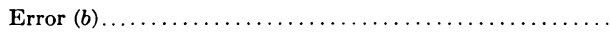 & 66 & 55.08 & 132 & 51.67 \\
\hline Plots $\ldots \ldots \ldots \ldots \ldots \ldots \ldots \ldots \ldots \ldots \ldots \ldots \ldots \ldots \ldots$ & 95 & $1,302.45 \dagger$ & 191 & $1,895.54 \dagger$ \\
\hline 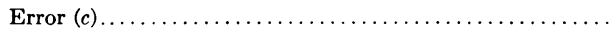 & 288 & 8.62 & 576 & 28.93 \\
\hline Total. $\ldots \ldots \ldots \ldots \ldots \ldots \ldots \ldots \ldots \ldots \ldots \ldots$ & 383 & & 767 & \\
\hline
\end{tabular}

$\dagger F$ values indicate significance at the 1 per cent level (odds 99:1).

TABLE 8

EFFECT OF CUTTING AND THRESHING DATES ON THE PERCENTAGE OF BROWN BEANS; TWO VARIETIES, SUTTER COUNTY, 1953

\begin{tabular}{|c|c|c|c|c|c|c|c|}
\hline \multirow{2}{*}{ Variety } & \multirow{2}{*}{ Cutting dates } & \multicolumn{6}{|c|}{ Per cent of brown beans } \\
\hline & & Thresh 0 & Thresh 1 & Thresh 2 & Thresh 3 & L.S.D. & Average \\
\hline $\begin{array}{r}\text { Sutter } \\
\text { Pink }\end{array}$ & 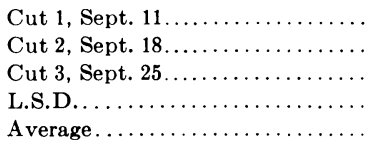 & $\begin{array}{r}0.9 \\
9.4 \\
37.1 \\
5.3 \\
15.8\end{array}$ & $\begin{array}{r}8.4 \\
22.1 \\
46.8 \\
5.3 \\
25.7\end{array}$ & $\begin{array}{r}17.3 \\
22.9 \\
53.8 \\
5.3 \\
31.3\end{array}$ & $\begin{array}{r}31.9 \\
29.6 \\
72.9 \\
5.3 \\
44.8\end{array}$ & $\begin{array}{l}2.2 \\
2.2 \\
2.2 \\
\ldots \\
3.0\end{array}$ & $\begin{array}{r}14.6 \\
21.0 \\
52.6 \\
2.2 \\
29.4\end{array}$ \\
\hline $\begin{array}{l}\text { Standard } \\
\text { Pink }\end{array}$ & 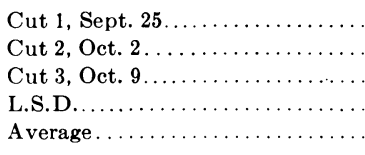 & $\begin{array}{r}3.9 \\
25.4 \\
40.2 \\
5.3 \\
23.2\end{array}$ & $\begin{array}{r}34.8 \\
39.9 \\
40.7 \\
5.3 \\
38.5\end{array}$ & $\begin{array}{r}32.9 \\
42.2 \\
51.9 \\
5.3 \\
42.3\end{array}$ & $\begin{array}{r}36.0 \\
48.8 \\
62.0 \\
5.3 \\
48.9\end{array}$ & $\begin{array}{l}2.2 \\
2.2 \\
2.2 \\
\cdots \\
3.0\end{array}$ & $\begin{array}{r}26.9 \\
39.0 \\
48.7 \\
2.2 \\
38.2\end{array}$ \\
\hline $\begin{array}{l}\text { Average } \\
\text { of two } \\
\text { varieties }\end{array}$ & 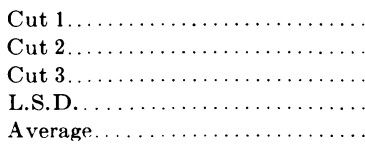 & $\begin{array}{r}2.4 \\
17.4 \\
38.6 \\
2.7 \\
19.5\end{array}$ & $\begin{array}{r}21.6 \\
31.0 \\
43.7 \\
2.7 \\
32.1\end{array}$ & $\begin{array}{r}25.1 \\
32.5 \\
52.8 \\
2.7 \\
36.8\end{array}$ & $\begin{array}{r}33.9 \\
39.2 \\
67.4 \\
2.7 \\
46.9\end{array}$ & $\begin{array}{l}3.1 \\
3.1 \\
3.1 \\
\cdots \\
2.1\end{array}$ & $\begin{array}{r}20.8 \\
30.0 \\
50.6 \\
1.8 \\
33.8\end{array}$ \\
\hline
\end{tabular}

made them appear still smaller. The differences between the second and third dates of cutting were small. The average of all varieties at cut 2 was 32.2 and at cut 3 was 32.7 grams per 100 beans, a difference of only 0.5 gram, but this is statistically significant.

In most cases the beans which were dried artificially were lighter in weight 
than those cut at the same time and field-dried. The two exceptions are the third cutting date for Sutter Pink and Salinas Pink. The average of all varieties shows the thresh 0 treatment was significantly lower than thresh 1 at all cutting dates. This may be accounted for by assuming that the artificially dried beans lost more moisture than those dried in the field. Another feature which indicated differences may be due to moisture content is that in all varieties except Standard Pink, the beans of the first cutting date were heavier when they were field-dried one week than when allowed to dry two weeks. The average of all varieties shows a difference of 1.1 grams, where 0.5 was significant at the 5 per cent level. Comparing the first and the third threshing date where the beans were dried three weeks in the field, the differences were more extreme. However, thresh 3 was not significantly lower than thresh 2 for all varieties. The effect of cutting and threshing on the four varieties at Davis are shown graphically in figure 5.

\section{THE EFFECTS ON PERCENTAGE OF BROWN BEANS}

Sutter County. The statistical analysis of the data on percentage of brown beans in Sutter County is shown in table 7. Every variable in the experiment except replications gave highly significant differences: varieties, dates of cutting, dates of threshing, and all the interactions.

In table 8 the average percentage of brown beans is given for each cutting and threshing date for the two varieties tested. All differences were highly significant. The average percentage of brown beans for all treatments was 29.4 for Sutter Pink and 38.2 for Standard Pink. The difference is highly significant since the least significant difference is 2.6 per cent. The Sutter Pink had lower percentages in nine of the twelve treatments, including all the threshing dates of the first and second cutting dates. The percentages were greater in three of the four threshing dates in the third date of cutting. From the data of this experiment one must conclude that Sutter Pink is less inclined to turn brown than the Standard Pink.

An examination of the figures in table 8 shows that for Sutter Pink there was a consistent increase in percentage of browning for each succeeding cutting date and for each succeeding threshing date. All of these increases were highly significant. The earliest harvest (cut 1 thresh 0 ) had 0.9 per cent and the latest (cut 3 thresh 3 ) had 72.9 per cent, an increase of 72 per cent in a period of five weeks. The browning then increases with time of exposure, whether the beans are exposed before or after they are cut and windrowed.

With Standard Pink the same tendency was shown. Browning was faster in the earlier stages, but reached only 62.0 per cent in the plots with the greatest exposure time. Since time of exposure seems to be the important factor in browning, the data from table 8 can be reassembled to give the percentage of brown beans at weekly intervals. These values are shown in table 9 . The average weekly figures of both varieties are charted in figure 6 . This figure shows clearly how time of exposure affected the browning of the beans. In the first week the browning was about 20 per cent and thereafter about 10 per cent per week.

Davis. The analysis of variance of the data on the percentage of brown beans in the Davis experiments is shown in table 7. Highly significant differences were found between varieties, cutting dates, threshing dates, and all 
the interactions. The data for each of the twelve harvest treatments on each of the four varieties is shown in table 10 .

The average percentage of brown beans for the four varieties was: Early Pink, 49.7 ; Sutter Pink, 44.0; Standard Pink, 59.5; and Salinas Pink, 57.1. The average of the four varieties was 52.6 , with a least significant difference

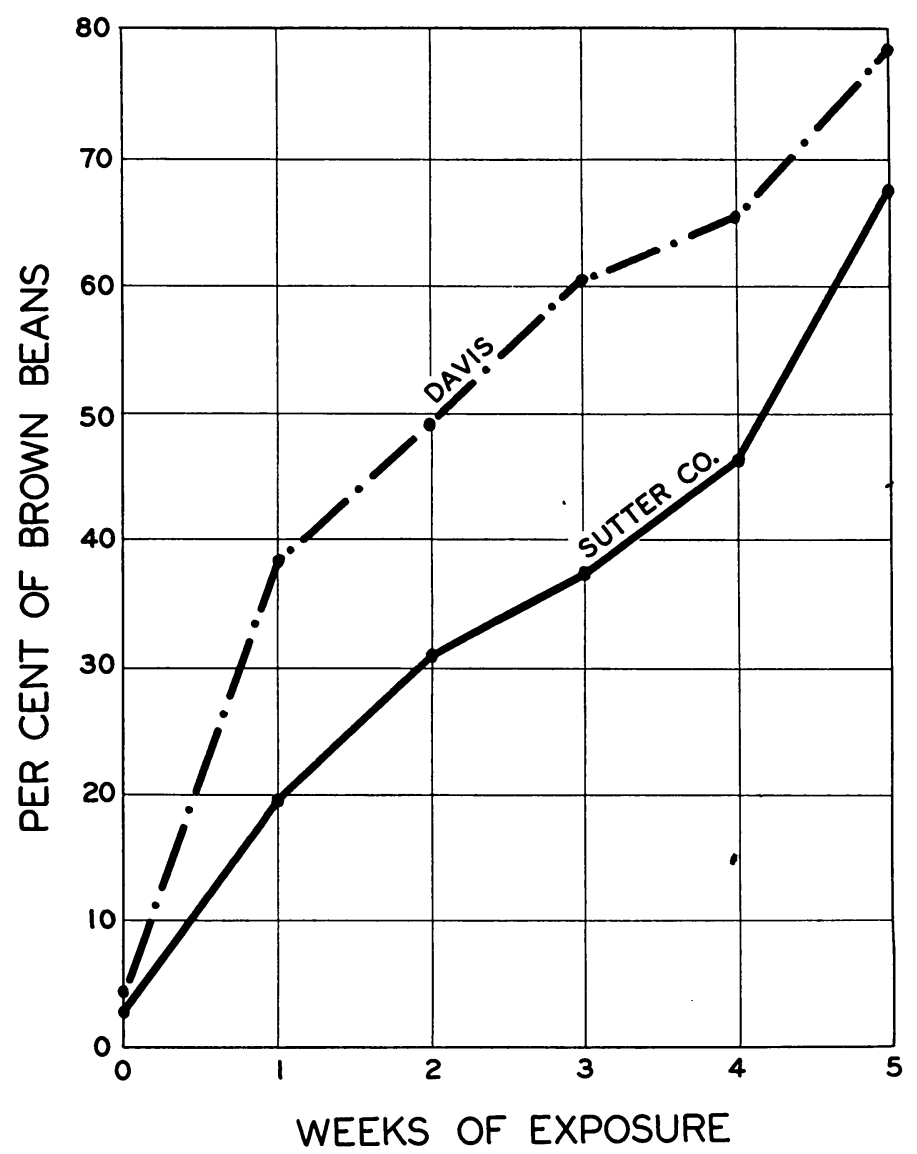

Fig. 6. Effect of exposure on percentage of brown beans; Sutter Pink and Standard Pink varieties in Sutter County and at Davis, 1953.

of 2.1, indicating that each variety was significantly different from every other. The general results are similar to those obtained in Sutter County.

The variety Salinas Pink gave aberrant results in one treatment-cut 1 thresh 1 . This is a late-maturing variety. The first cutting was made on October 6 . At that time the plants were very leafy and green. This treatment was threshed one week later. One week at that time of the year was not enough to completely dry the material, so the threshed beans were high in moisture. Unfortunately, the threshed beans were stored in an unheated room, so further drying was limited. When the samples were drawn for color and size determinations in February, two of the four samples of this treatment were 
slightly moldy and greatly discolored. Results from these plots, perhaps, should be discarded. They were included because they show the effect of moisture content on the discoloration. The average of the four samples of this treatment was 74.0 per cent brown, while the cut 2 thresh 0 samples, which were exposed the same length of time in the field, had only 28.8 per cent.

TABLE 9

EFFECT OF TIME OF EXPOSURE ON PERCENTAGE OF BROWN BEANS, TWO VARIETIES, SUTTER COUNTY, 1953

\begin{tabular}{|c|c|c|c|c|}
\hline \multirow{2}{*}{$\begin{array}{l}\text { Time of } \\
\text { exposure }\end{array}$} & \multirow{2}{*}{ Treatments } & \multicolumn{3}{|c|}{ Per cent of brown beans } \\
\hline & & $\begin{array}{l}\text { Sutter } \\
\text { Pink }\end{array}$ & $\begin{array}{c}\text { Standard } \\
\text { Pink }\end{array}$ & Average \\
\hline 0 weeks & $\mathrm{C} 1, \mathrm{~T} 0 \ldots \ldots \ldots$ & 0.9 & 3.9 & 2.4 \\
\hline 1 week & 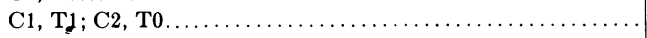 & 8.9 & 30.1 & 19.4 \\
\hline 2 weeks & 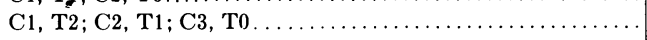 & 25.5 & 37.7 & 31.5 \\
\hline 3 weeks & 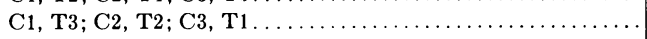 & 33.9 & 39.6 & 36.7 \\
\hline 4 weeks & 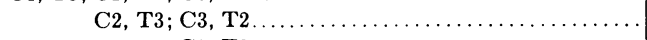 & 41.7 & 50.4 & 46.0 \\
\hline 5 weeks & 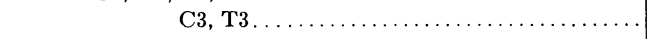 & 72.9 & 62.0 & 67.4 \\
\hline
\end{tabular}

TABLE 10

EFFECT OF CUTTING AND THRESHING DATES ON THE PERCENTAGE OF BROWN BEANS, FOUR VARIETIES, DAVIS, 1953

\begin{tabular}{|c|c|c|c|c|c|c|c|}
\hline \multirow{2}{*}{ Variety } & \multirow{2}{*}{ Cutting dates } & \multicolumn{6}{|c|}{ Per cent of brown beans } \\
\hline & & Thresh 0 & Thresh 1 & Thresh 2 & Thresh 3 & L.S.D. & Average \\
\hline \multirow{5}{*}{ Early Pink } & Cut 1, Sept. $1 \ldots \ldots \ldots \ldots \ldots \ldots$ & 3.6 & 38.8 & 36.6 & 41.6 & 5.0 & 30.1 \\
\hline & Cut 2, Sept. $8 \ldots \ldots \ldots \ldots \ldots \ldots$ & 23.8 & 45.0 & 58.2 & 74.5 & 5.0 & 50.4 \\
\hline & Cut 3 , Sept. $15 \ldots \ldots \ldots \ldots \ldots \ldots$ & 58.9 & 56.2 & 70.8 & 88.7 & 5.0 & 68.7 \\
\hline & 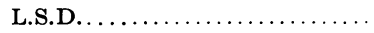 & 5.0 & 5.0 & 5.0 & 5.0 & $\ldots$ & 2.5 \\
\hline & Average......... & 28.8 & 46.6 & 55.2 & 68.3 & 2.9 & 49.7 \\
\hline \multirow{5}{*}{$\begin{array}{r}\text { Sutter } \\
\text { Pink }\end{array}$} & Cut 1 , Sept. $8 \ldots$ & 2.5 & 32.9 & 44.4 & 49.5 & 5.0 & 32.3 \\
\hline & Cut 2, Sept. 15.. & 32.0 & 29.3 & 41.3 & 54.2 & 5.0 & 39.2 \\
\hline & Cut 3, Sept. 22.. & 51.6 & 56.9 & 62.8 & 70.6 & 5.0 & 60.5 \\
\hline & L.S.D......... & 5.0 & 5.0 & 5.0 & 5.0 & $\ldots$ & 2.5 \\
\hline & Average $\ldots \ldots \ldots$ & 28.7 & 39.7 & 49.5 & 58.1 & 2.9 & 44.0 \\
\hline \multirow{5}{*}{$\begin{array}{l}\text { Standard } \\
\text { Pink }\end{array}$} & Cut 1, Sept. 29. & 3.9 & 56.3 & 58.7 & 76.1 & 5.0 & 48.7 \\
\hline & Cut 2, Oct. 6... & 34.4 & 67.4 & 69.0 & 69.4 & 5.0 & 60.0 \\
\hline & Cut 3 , Oct. $13 \ldots \ldots \ldots \ldots \ldots \ldots$ & 47.2 & 70.7 & 75.5 & 85.4 & 5.0 & 69.7 \\
\hline & L.S.D.................... & 5.0 & 5.0 & 5.0 & 5.0 & $\ldots$ & 2.5 \\
\hline & Average.$\ldots \ldots \ldots \ldots \ldots \ldots \ldots$ & 28.5 & 64.8 & 67.7 & 76.9 & 2.9 & 59.5 \\
\hline \multirow{5}{*}{$\begin{array}{c}\text { Salinas } \\
\text { Pink }\end{array}$} & Cut 1 , Oct. $6 \ldots \ldots \ldots \ldots \ldots \ldots$ & 3.3 & 74.0 & 49.4 & 64.6 & 5.0 & 47.8 \\
\hline & Cut 2, Oct. 13.. & 28.8 & 62.7 & 56.4 & 68.6 & 5.0 & 54.1 \\
\hline & Cut 3 , Oct. 20 . & 53.4 & 66.0 & 78.8 & 79.1 & 5.0 & 69.3 \\
\hline & L.S.D........ & 5.0 & 5.0 & 5.0 & 5.0 & $\ldots$ & 2.5 \\
\hline & Average......... & 28.5 & 67.6 & 61.5 & 70.7 & 2.9 & 57.1 \\
\hline \multirow{5}{*}{$\begin{array}{l}\text { Average } \\
\text { of four } \\
\text { varieties }\end{array}$} & Cut $1 \ldots \ldots \ldots \ldots \ldots \ldots \ldots \ldots$ & 3.3 & 50.5 & 47.3 & 57.9 & 2.5 & 39.8 \\
\hline & Cut $2 \ldots$ & 29.7 & 51.1 & 56.2 & 66.7 & 2.5 & 50.9 \\
\hline & Cut $3 \ldots$. & 52.8 & 62.5 & 72.0 & 80.9 & 2.5 & 67.0 \\
\hline & L.S.D. . & 2.5 & 2.5 & 2.5 & 2.5 & $\ldots$ & 1.3 \\
\hline & Average... & 28.6 & 54.7 & 58.5 & 68.5 & 1.5 & 52.6 \\
\hline
\end{tabular}


Table 11 was made up from the Davis experiments in the same manner as was table 9 for the Sutter County tests. It shows the effect of length of the exposure on the percentage of brown beans. The average percentage of brown beans with 0 exposure was 3.3 per cent. In the first week of exposure it rose to 40.1 per cent and increased about 10 per cent per week thereafter, so that at the end of five weeks it was 80.9 per cent. The rate of browning was thus higher at Davis than in Sutter County. This difference is demonstrated further in figure 6 , which shows the average percentage of brown beans of the same two varieties at both locations.

In both locations the average and also (except for Standard Pink in Sutter County) the maximum percentage of brown beans was less for the variety

TABLE 11

\section{EFFECT OF TIME OF EXPOSURE ON PERCENTAGE OF BROWN BEANS,} FOUR VARIETIES, DAVIS, 1953

\begin{tabular}{|c|c|c|c|c|c|c|}
\hline \multirow{2}{*}{$\begin{array}{l}\text { Time of } \\
\text { exposure }\end{array}$} & \multirow{2}{*}{ Treatments } & \multicolumn{5}{|c|}{ Per cent of brown beans } \\
\hline & & $\begin{array}{c}\text { Early } \\
\text { Pink }\end{array}$ & $\begin{array}{l}\text { Sutter } \\
\text { Pink }\end{array}$ & $\begin{array}{l}\text { Standard } \\
\text { Pink }\end{array}$ & $\begin{array}{c}\text { Salinas } \\
\text { Pink }\end{array}$ & Average \\
\hline 0 weeks & C1, T0. . & 3.6 & 2.5 & 3.9 & 3.3 & 3.3 \\
\hline 1 week & $\mathrm{C} 1, \mathrm{~T} 1 ; \mathrm{C} 2, \mathrm{~T} 0 \ldots \ldots \ldots$ & 31.3 & 32.5 & 45.4 & 51.4 & 40.1 \\
\hline 2 weeks & $\mathrm{C} 1, \mathrm{~T} 2 ; \mathrm{C} 2, \mathrm{~T} 1 ; \mathrm{C} 3, \mathrm{~T} 0$. & 46.8 & 41.8 & 57.9 & 55.2 & 50.4 \\
\hline 3 weeks & $\mathrm{C} 1, \mathrm{~T} 3 ; \mathrm{C} 2, \mathrm{~T} 2 ; \mathrm{C} 3, \mathrm{~T} 1$. & 52.0 & 49.2 & 71.9 & 62.3 & 58.9 \\
\hline 4 weeks & $\mathrm{C} 2, \mathrm{~T} 3 ; \mathrm{C} 3, \mathrm{~T} 2$ & 72.7 & 58.5 & 72.5 & 73.7 & 69.4 \\
\hline 5 weeks & $\mathrm{C} 3, \mathrm{~T} 3$ & 88.7 & 70.6 & 85.4 & 79.1 & 80.9 \\
\hline
\end{tabular}

Sutter Pink than any other tested. It would seem, therefore, that the problem of browning cannot be reduced by a substitution for the Sutter Pink.

Method of Exposure, Both Localities. Now it would be interesting to know whether there was any effect of the method of exposure on the rate of browning. After the first cutting date the beans could be exposed in two ways, either standing where no protection was given or piled in windrows where the beans in the center of the windrows could possibly be protected. From the twelve harvest treatments, ten can be set up for comparison. There were two harvest treatments with one week of exposure-cut 1 thresh 1 and cut 2 thresh 0 . The first was in the windrow, the second standing. Three treatments were exposed two weeks: cut 1 thresh 2 was in the windrow two weeks; cut 2 thresh 1 was exposed one week each way; and cut 3 thresh 0 was standing both weeks. Three treatments were exposed for three weeks: cut 1 thresh 3 was in the windrow all three weeks; cut 2 thresh 2 was standing one week and two weeks in the windrow; and cut 3 thresh 1 was standing two weeks and in the windrow one week. Two treatments were exposed four weeks: cut 2 thresh 3 was standing one week and in the windrow three weeks; and cut 3 thresh 2 was exposed two weeks each way.

In figure 7 the effect of method of exposure on the percentage of brown beans is given for Sutter County and Davis. The data for these diagrams were taken from the bottom of table 8 for Sutter County and from table 10 for Davis. For Sutter County each bar represents the average of 8 plots with a 
least significant difference of 2.7 per cent. For Davis each bar represents the average of 16 plots and the least significant difference is 2.5 per cent. Thus small differences are significant.

In the plots exposed one week the percentage of brown beans was considerably higher in those in the windrow than in those left standing. This is inter-

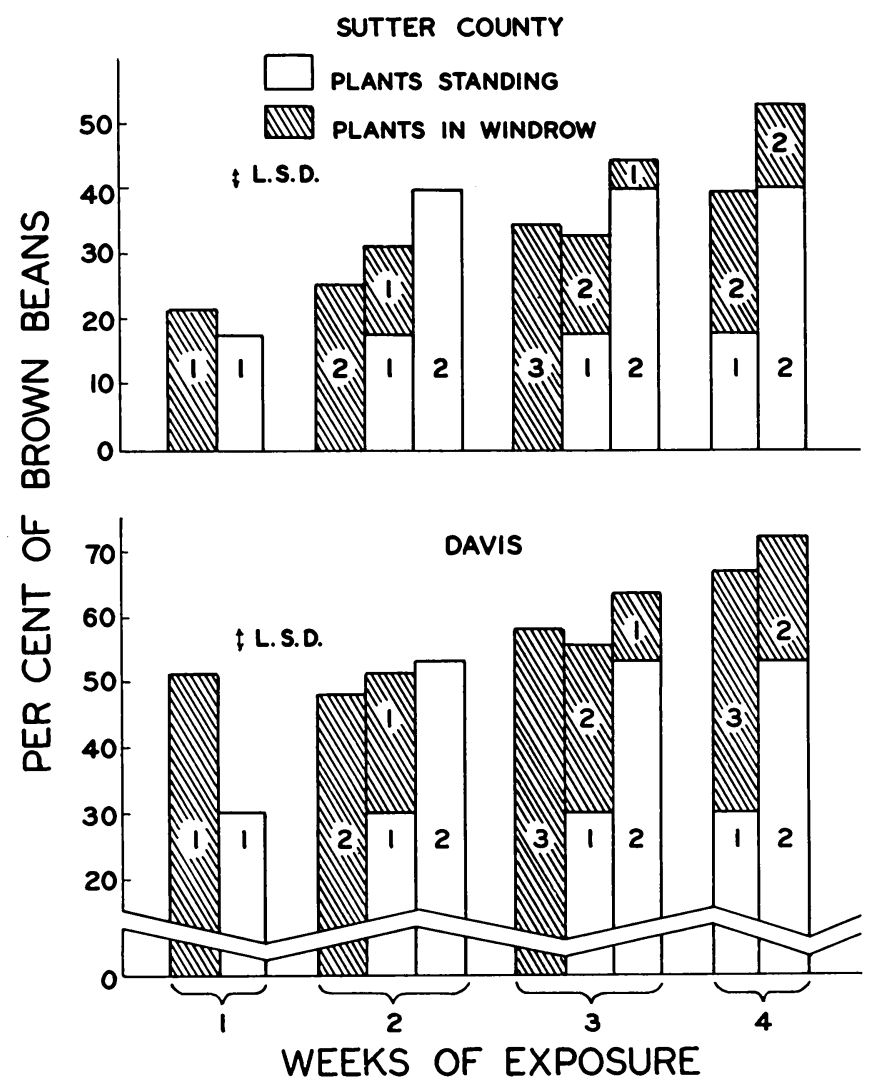

Fig. 7. Effect of method of exposure on percentage of brown beans; two varieties in Sutter County, four varieties at Davis, 1953. The figures on the bars are weeks of exposure by the indicated method.

preted to mean that since the cut 1 treatment was intentionally made a week early the plants left standing were still maturing and hence not affected by exposure as much as those which were cut. In plots exposed two to four weeks there was a small but consistent increase in the percentage of brown beans in the plots which were standing over those in the windrow.

The two methods of exposure can also be compared in the treatments that had two or more weeks of total exposure time. In Sutter County the extension of the standing time one week resulted in an average increase of 7.4 per cent of brown beans. In Davis the increase was 3.1 per cent. Both are significant. When the length of standing time was extended two weeks the percentage of brown beans increased 11.7 per cent in Sutter County, or 5.9 per cent per 
week. The corresponding increase at Davis was 5.1 per cent, or 2.6 per cent per week. These differences are statistically significant. It is apparent, then, that plants left standing after the beans are mature have a higher percentage of brown beans than those exposed an equal length of time in the windrow. The difference is due to the protection of the beans in the windrows.

\section{CONCLUSIONS}

Three things were measured in these studies: yield, seed size, and percentage of brown beans. The experiments conducted at the two locations gave similar results.

Yield reductions between normal cutting dates and the early cutting dates ranged from 95 to 788 pounds per acre. The average reduction was 318 pounds. Dates of threshing had no effect on yield.

The size of the beans was reduced by the early cutting. Differences between threshing dates were probably due to differences in moisture content: treatments with long exposures had lighter beans, presumably because they were drier.

In the harvest treatments significant differences were found in the percentage of brown beans in both cutting and threshing dates. The percentage of brown beans increased with time of exposure in every variety at each location. In exposure time the treatments ranged from 0 to 5 weeks. In that time the brown beans rose from between 1 and 4 per cent to between 62 and 89 per cent. There was a higher percentage of brown beans at Davis than in Sutter County for the same varieties.

Variety differences in the percentage of brown beans were significant. This may be due to real variety differences or to differences in the weather conditions encountered during the experiment, which ran from September to November. No rain fell during this period that would complicate the results, but there were great differences in the number of daylight hours, daily temperature, and the amount of morning dew. The variety with the lowest percentage of brown beans at both locations was Sutter Pink. This indicates that there would be no advantage in changing from the Sutter Pink variety.

Two methods of exposure were used: standing and in the windrow. During the first week the cut beans in the windrow suffered more browning than those which remained to mature a week longer. After the first week there was a slight but significant difference in favor of the bean plants exposed in the windrow. This difference was in the neighborhood of 2.5 to 7 per cent per week of exposure.

It is impossible to completely prevent browning because some takes place while the beans are curing before threshing. By cutting the beans early the amount of browning is reduced, but at the cost of reducing both yield and seed size, disadvantages which outweigh the possible advantages in improved color. The amount of browning is higher in the first week than in any similar length of time thereafter. But this week of exposure is necessary for curing. In order to keep browning to a minimum the grower should cut his beans as soon as they reach maturity and complete the threshing as soon as they are dry. Even a few days of overexposure results in avoidable deterioration of color. 
The journal Hilgardia is published at irregular intervals, in volumes of about 600 pages. The number of issues per volume varies.

Subscriptions are not sold. The periodical is sent as published only to libraries, or to institutions in foreign countries having publications to offer in exchange.

You may obtain a single copy of any issue free, as long as the supply lasts; please request by volume and issue number from:
Agricultural Publications
Room 22, Giannini Hall
University of California
Berkeley 4, California

The limit to nonresidents of California is 10 separate issues on a single order. $A$ list of the issues still available will be sent on request. 


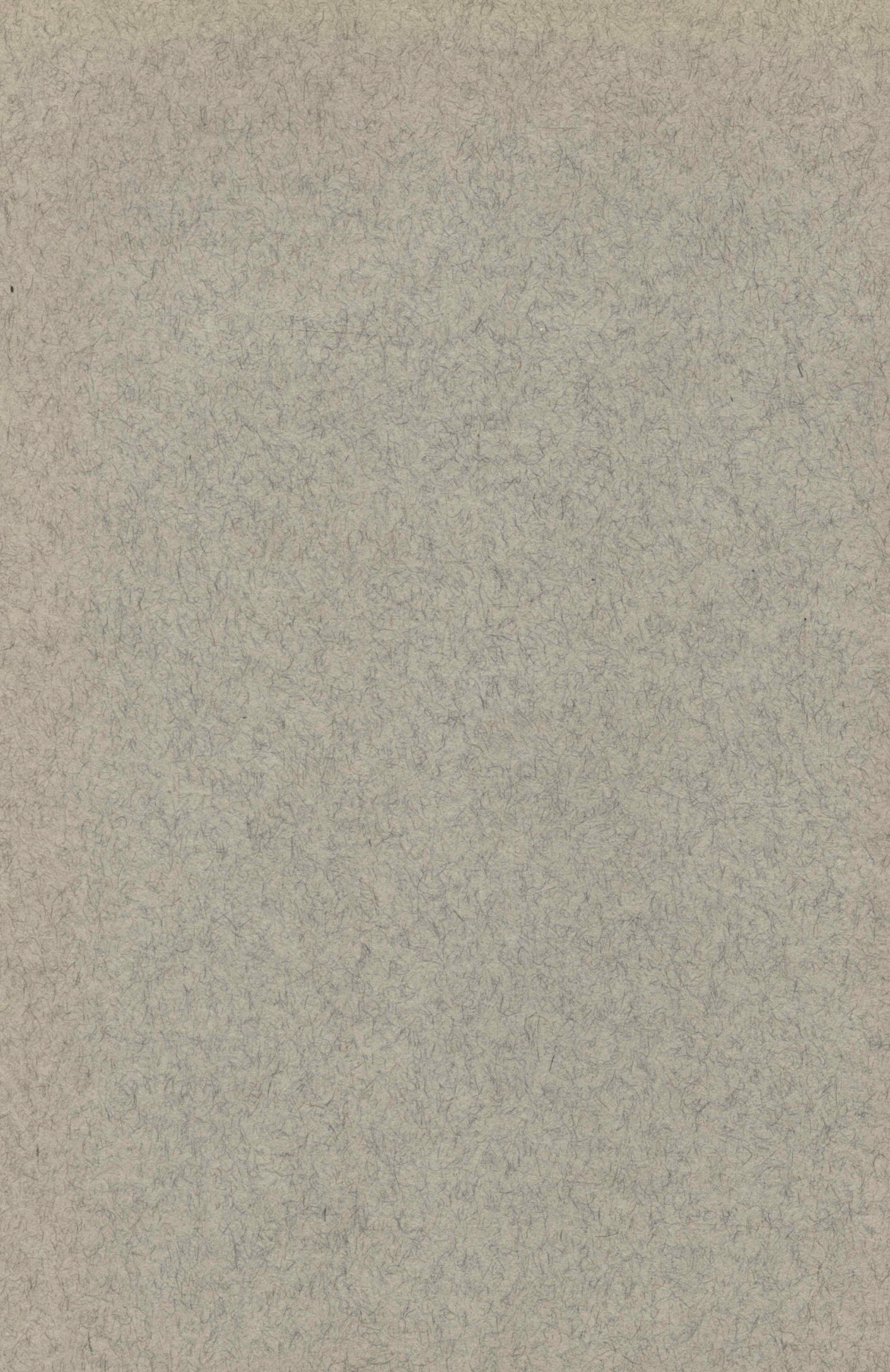

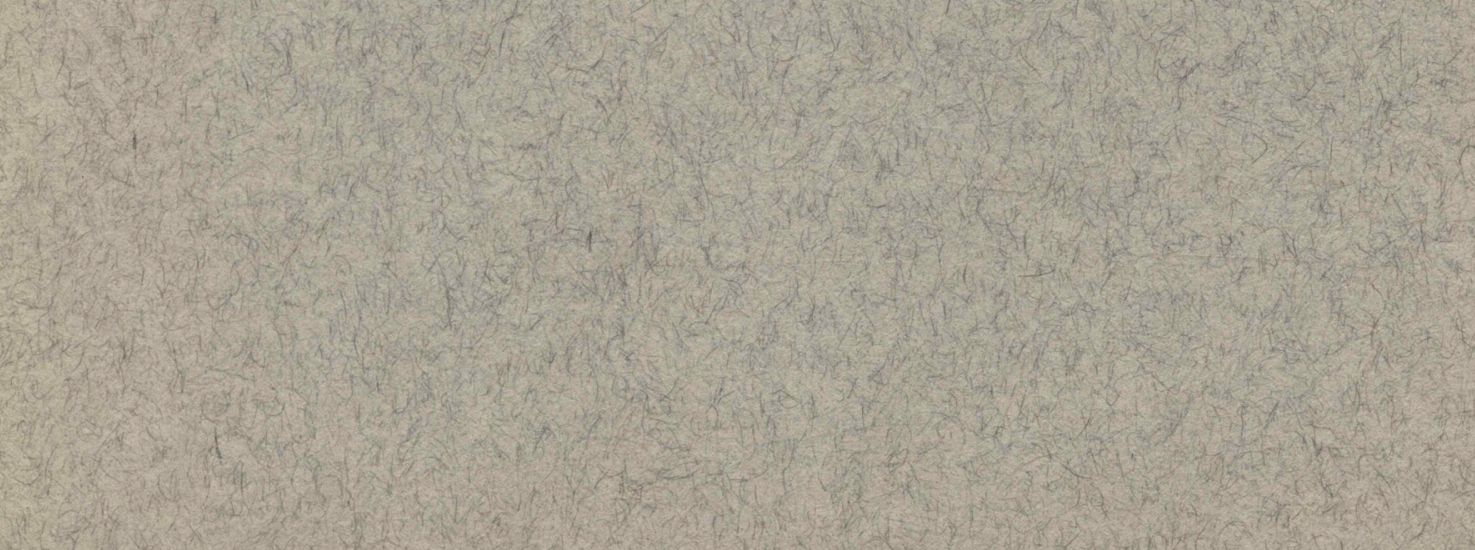

